\title{
The role of the disciples in the Jesus story communicated by Mark
}

Patrick J. Hartin

Department of New Testament

University of South Africa

PRETORIA

\begin{abstract}
This paper argues that the Gospels are to be taken seriously as communicative narratives. An attempt will be made to apply what scholars have presented under the study of narrative criticism to the Gospels themselves. In particular an attempt will be made to use the results of narrative criticism to gain an insight into the role that the character of the disciples as a group plays within the Gospel of Mark.

The disciples are called to be 'the insiders' to whom Jesus communicates the mystery of the kingdom. However, as the narrative progresses, the group of disciples is seen to change from that of 'insiders' to 'outsiders'.

Against this background of the development of the narrative it is arglted that the much disputed cnding of Mark 16:8 is highly appropriate to the entire narrative. The disciples have deserted Jesus out of fear. Concented with themselves and their own ambitions, Jesus' disciples are unable to appreciate Jesus' teaching on the true nature of God's nule. The reader is challenged to avoid those failings of the disciples and to imitate Jesus' example.
\end{abstract}

\section{INTRODUCTION}

Over the past century and a half the most successful method used by Biblical scholars in interpreting the New Testament has undoubtedly been the historical-critical method'. This method endeavoured to examine the Bible, and in particular the New Testament, in a methodological, objective way in order to trace above all the origin and development of the New Testament writings. While such an approach is vital for an understanding of the New Testament, it does not solve all the problems of interpretation. As with every science, new insights develop through the posing of new and different questions. In fact, it is the question we pose which often influences the method we use. More recently many new methods have emerged in the field of Biblical studies. These methods examine the text in a new light, revealing many new insights. These new methods do not reject the historical-critical method, but aim at supplementing it. 
One such approach is that of literary criticism - a wide field which encompasses many and varied approaches to the interpretation of a text. One of the more recent approaches to the interpretation of the Gospels is to take their character as narratives seriously. In other words one approaches the Gospels as texts or narratives in which an agent tells a story (Bal, 1988:5). That the Gospels should be approached as narratives, is perhaps an obvious perception, but it is not one which pre-occupied scholars of the New Testament over much. Not until the last two decades did New Testament scholars begin to take this aspect of these writings seriously. As Norman Perrin argued two decades ago. Since "the evangelists are genuinely authors," one should construct a "general literary criticism" of the Gospels by having recourse to what is being done in the field of general literary studies (Perrin, 1972:17, 9-10).

It is my contention that a narratological approach to the understanding of the Gospels is called for in order to take seriously the nature of the Gospels themselves. What I intend to do in this paper is to illustrate how a use of aspects of narrative criticism can contribute to a deeper understanding of the Gospels themselves by focusing attention upon the character-role of the disciples.

\section{THE TEXT AS NARRATIVE}

The historical-critical method focused attention largely upon the individual units which went to make up the text. Now, the embracing wholeness of the text occupies center stage, whereby the original unity of the story is examined - in our case the original unity of the Markan story. Within this unity and contributing to it, the characters unfold, the plot emerges and the point of view of the narrative develops. The Gospel of Mark is a unified story wherein the main consolidating factor is the central figure of Jesus. The disciples also play a role which helps to unite this entire narrative (Tannehill, 1977:388). Within the overall historical-critical method redaction criticism had paid attention to the role of the redactor/author in the construction of a work. However, there is a wide difference between the work of redaction criticism and that of narrative criticism. Redaction criticism gave its main attention to the changes made by the redactor in the sources at his disposal. In other words the modification of the tradition was the main focus of attention (Perrin, 1972:9-10). With narrative criticism the main focus has shifted to an examination of how the story is told, and how it communicates with the reader. A shift in emphasis has occurred from a focus upon the author (redactor) to a focus upon the text and how it communicates with the reader.

A further consequence of the unity is that the author is the one responsible for the narrative world which now exists in its own right (Rhoads, 1982:412-413) independently of the world of Jesus or of Mark (Petersen, 1980:25-50). In interpreting the story of 
Mark from a narratological perspective, one does not try to see it as a mirror of the world outside the text. The characters and events within the story refer to characters and events within that story-world. The text is a creation of a certain world, a certain era, and this certainly will impinge upon the text. When reading a text one attempts to draw together connections between events and characters within the story-line. Uspensky (1973:137) paints very well what happens when one enters the fictional world of a narrative:

In a work of art ... there is presented to us a special world, with its own space and time, its own
ideological system, and its own standards of behavior. In relation to that world, we assume (at
least in our first pereeptions of it) the position of an alien spectator, which is necessarily
external. Gradually we enter into it, becoming more familiar with its standards, accustoming
oursclves to it, until we begin to perceive this world as if from within, rather than from without.
We, as readers or observers, now assume a point of view internal to the particular work. Then
we are faced with the necessity of leaving that world and returing to our own point of vicw, the
point of view lrom which we had to a large extent disengaged ourselves while we were
experiencing (reading, secing and so forth) the artistic work.

In the following examination attention will be given to the character-role of the disciples in the narrative of the Gospel of Mark and the ways in which they emerge within the story-line, whether in a positive or negative way. ${ }^{1}$

\section{THE ROLE OF TIIE CIIARACTERS IN THE NARRATIVE OF THE GOSPEL OF MARK}

Every story comprises three basic elements: plot, characters and setting. These same elements play a vital role in the Gospels. I am not trying to argue that all aspects of a modern novel are to be found in the ancient narrative. As Tannehill (1977:387) argues:

However, there are qualities which all narratives share and further qualities which various narratives may share, even when some make use of historical fact, if the author has a strong, creative role.

One essential aspect of the narrative is the choice that the author makes in the material which he/she uses and then how he/she chooses to tell the story. This is seen especially in the characters within the story. Consequently, it is imperative that the

1 Because I focus attention on the role of the disciples as a character-group in the Gospel of Mark, I do not intend to say that this is the only or the all important aspect of consideration within the Gospel. It is one (albeit important) aspect of the development of the narrative of the Gospel of Mark. 
interpreter understands the role and way in which the characters function within the narrative. While a character is normally seen as an individual, a group can also function in this particular way. They can utter responses and the plot of the story can unfold according to their reactions. I wish to examine one particular group, namely the disciples, by giving attention to the character-role they play within one particular New Testament writing, namely the Gospel of Mark.

One might ask with justification: 'Why approach this topic once again, since it has been considered quite often in the past, particularly in the last two decades?' This question is evident from a brief perusal of the works consulted at the end of this paper. Freyne (1982:7) drew attention to this same question in his study on the disciples in Mark:

The disciples in Mark, a topic which has repcatcdly engaged the schorarly attention of Professor Ernest Best, might appear to defy any further clarification, at least in the present state of Markan studics. In the recent past the topic has been variously treated from the historical, theological and literary points of view, without any clear consensus on the several questions that arise from the highly distinctive presentation that they receive in the earliest gospel.

My main purpose at looking at this topic once again is twofold: First of all, while there have been so many different viewpoints taken on the disciples in Mark, I feel that a narratological approach is the way forward in the midst of this empasse. A consideration of the role of the character of the disciples solely as a literary device within the narrative world of the Gospel itself could contribute to a better understanding of the Gospel. Secondly, I have always been intrigued by the ending of the Gospel of Mark, and I wish to show that to a large extent the perspective adopted by the narrator to the character of the disciples within the development of the narrative offers a possible solution to the enigma of the ending of the narrative.

Next to the person of Jesus in the Gospel of Mark that group referred to as disciples must surely be the most important. In the narrative the term disciples refers chiefly to twelve people whom Jesus called to follow him. ${ }^{2}$ And among these twelve, three (Peter, James, and John) form an inner circle. These three are the only ones who actually speak in the narrative, although a fourth disciple, Judas, is the one who hands Jesus over to the authorities.

2 Munro (1982:229) expresses the perception very well: "The dominant impression in Mark till 15:39 is of a Jesus who went about his mission surrounded by a small group of men, with women usually encountered in private. There are, however, hints that women were present among his crowd following, and also the implication that the inner circle of disciples included more that twelve men." 
The narrator ${ }^{3}$ presents the role of the disciples in both a favourable and unfavourable way. There is in fact a decided progression (or regression?) from being loyal supporters of Jesus, to followers who fail to understand Jesus' message and end up as an obstacle for him. This ambivalence pervades the narrative of Mark: the disciples are on the side of Jesus, yet at the same time they fail to fulfil the task to which Jesus has called them (Rhoads \& Michie, 1982:123).

The disciples become the means by which Jesus is able to develop his message. Much of Jesus' teaching occurs through the way in which he takes issue with the disciples' response, or the way in which he corrects their understanding of (or failure to understand) his teaching.

The attitude of the reader ${ }^{4}$ towards the disciples also changes. At first, when the disciples were called, the reader was led to feelings of expectation and sympathy

3 The narrator is a term used to indicate the one who tells the story within the narrative. As such the narrator is to be distinguished from the author. In fact the narrator is a literary device which the author uses in order to tell the story. The narrator tells the story of Mark's Gospel in the third person and is omniscient and omnipresent. Behind every episode is the narrator who is able to give insights into the thoughts and motivations of every character and ultimately to sec the whole story in its wider dimension and is able to communicate thesc insights to the reader.

A characteristic example of this omniscience of the author of the Gospel of Mark is the very way in which he opens the Gospel narrative: "The beginning of the good news of Jesus Christ, the Son of God" (Mk 1:1). Here, the narrator shows his understanding of Jesus as the Christ, the Son of God. He shares this understanding with the reader right from the beginning of the narrative. However, the understanding is something which the characters in the story do not immediately know (Fowler, 1978:118-122). In the narrative they only come to understand through a long and arduous struggle.

Distinguished from the narrator is the implied author and the autior. The implied author is the picture that one constructs from the narrative itsclf regarding the author, in particular the "'norms and choices' (standards of judgment) implicit in a work" (Rhoads, 1982:422) norms and choices which are operative throughout the narrative. This implied author is not identical with the author, as can be seen by looking at a number of works by the same author. The implied author is a construct of the actual author. As Uspensky (1973:11) says, the viewpoint of the implied author "is not that of the (actual) author's world view in general, but only the viewpoint which the author adopts for the organization of the narrative in a given work".

4 Although 1 am employing the term reader throughout this paper, it should be kept in mind that Mark's Gospel was in fact written in order to be read aloud, not silently as in our culture. In actual fact one should perhaps speak about the first hearers of the Gospel, as well as about the implied hearers of the narrative. However, I do not think that the terms hearer or reader are necessarily to be seen as two contrasting terms. Both oratory and rhetoric use the same techniques. The terms merely present different shifts in emphasis in 
because the disciples were the ones specially chosen by Jesus to whom he would communicate his message. With time the reader is led to correct this initial impression. Although the disciples identify Jesus as the Messiah (Mk 8:29), they cannot accept the fact that he is to suffer and die (Mk 8:32). When confronted with the reality of the fate of Jesus in Jerusalem, they abandon Jesus.

I shall examine the role that the character of the disciples plays in the narrative, and the way in which the perceptions of the reader changes with regard to them. This I shall do by following closely the narrative of the Gospel of Mark.

\section{THE CALL OF THE DISCIPLES TO LOYALTY (Mark 1:1-4:34)}

Attention will be given to selective episodes within the story which help to illustrate the role the disciples play within the narrative. Mark 1:16 begins the narration of the call of the first disciples with the call of two sets of brothers. The narrator presents these disciples as responding immediately to Jesus - they leave their nets, their occupation, their families, and follow Jesus to become fishers of men. "... and they left their father Zebedee in the boat with the hired men, and followed him" (Mk 1:20). The command of Jesus: "Follow me and I will make you fish for people" (Mk 1:16) gives the reader something by which s/he can judge the responses of the disciples throughout the narrative (Tannehill, 1977:396).

Even later in the narrative these qualities of giving a ready response to the instructions of Jesus continue to emerge. For example, they willingly go up a mountain with Jesus where he commissions them (Mk 3:13). They constantly follow his instructions to set out by boat to cross the Sea of Galilee (Mk 4:35); they help him in feeding the thousands of people ( $\mathrm{Mk} \mathrm{6:34-44;} \mathrm{and} \mathrm{8:1-10).} \mathrm{In} \mathrm{the} \mathrm{final} \mathrm{week} \mathrm{they} \mathrm{procure} \mathrm{a} \mathrm{donkey}$ on which Jesus (Mk 11:2) can enter Jerusalem; they also make the arrangements for the celebration of the Passover meal (Mk 14:13).

Chapter $4^{5}$ contains a parable discourse which emphasizes that an understanding of the kingdom is given to the disciples and not to those who are against the Gospel. The

approaching the text in an aural or in a visual way (Rhoads, 1982:425).

5 In what follows I am especially indebted to W.H. Kelber (1979; 1987 and 1988), Rhoads (1982:411-434), and Rhoads \& Michic (1982) who were among the first to take the narrative aspect seriously and to treat the Gospel of Mark as a story to be read as such in its own right. 
world is divided into two categories: the 'insiders' and the 'outsiders'. I am indebted to Kelber (1979:2) for this distinction between 'insiders' and 'outsiders' - a distinction which to my mind operates as a central aspect throughout the narrative of Mark's Gospel. The essence of this division into two groups lies in the parable discourse of Mark 4, where the disciples when they are alone with Jesus "asked him about the parables. And he said to them, "To you has been given the secret of the kingdom of God, but for those outside, everything comes in parables..." (Mk 4:10-12). The disciples are those who are privileged to be included among the 'insiders'. ${ }^{6}$

When the disciples question Jesus about the meaning of the parables, he comments: "To you has been given the secret of the kingdom of God, but for those outside, everything comes in parables" (Mk 4:11). Here, the disciples are shown to stand in a very privileged position in relation to Jesus. They are 'the insiders' to whom a deep understanding of the Kingdom is revealed. Distinguished from them are 'the outsiders', namely those who look, yet do not see; who listen and yet do not understand (Mk 4:12). This distinction between the insiders and the outsiders is important (Kelber, 1979:15; and 1988:43:2) and it forms a central aspect throughout the narrative of Mark's Gospel. The Gospel of Mark is presenting a narrative which is very dynamic: its characters move or shift their allegiance or understanding from insiders to outsiders. The author intends the reader to observe these vacillations in allegiance to the message of Jesus, to get glimpses of the disciples' fidelity, which then recedes once again into infidelity. The entire narrative emerges for the reader as a story of discipleship, of responses given to the message of Jesus. Later the narrator will demonstrate that the disciples themselves will turn their backs on this privileged position and show that they belong to the 'outsiders'.

While Mark 4:1-34 undoubtedly presents the disciples in a good light, the possibility of their negative reaction to Jesus and his message is already present or anticipated. In the entire section the emphasis is placed on hearing productively. The same call is addressed to the disciples. If they are not productive, they will be like the seed which fell on barren soil (Fay, 1989:79-80; and Tannehill, 1977:398).

The kingdom is in the process of becoming. Only those who are privileged to be the insiders will share in this kingdom and in a deepening understanding of it. The

6 Tannehill (1977:393-395) argues that the reader is encouraged to view the good qualities of the disciples in the beginning of the Gospel "so that he (sic) will feel more sharply the opposite development when it occurs". 
narrator shares his omniscient insight with us, the reader. Consequently, in following the narrative of the proclamation of the kingdom we, the readers, have been given the privileged position of being on the inside.

\section{THE DISCIPLES AS INSIDERS (Mark 4:35-8:21)}

The disciples are privileged witnesses, who begin as part of the insiders. But, ultimately they reject this privileged position. ${ }^{7}$ Throughout this narrative the disciples' lack of understanding, which is prompted by both fear and lack of faith, comes to the foreground. 8

This section commences with the miracle of the stilling of the storm (Mk 4:35-41).

7 It is noteworthy to see to what extremes scholars will go to save the disciples from any guilt. F.J. Matera (1989:153-172) is a good case in point. He exonerates the disciples from any moral guilt for their lack of understanding by laying the blame at God's door. "To summarize, hardness of heart is not merely the result of moral failure, although it is often manifested through moral failure. People's hearts are hardened so that they cannot understand. Hardness of heart paradoxically points to God's revelation which cannot be grasped apart from divine assistance ... hardness of heart is a situation in which human beings find themselves in face of God's revelatory action if God does not provide assistance to comprehend it" (Matera, 1989:158-159).

The problem here is that this approach fails to see the incomprehension of the disciples as a literary device - instead the search is made for some historical reason outside the world of the text. Not being able to find one, the scholar then ultimately resorts to God as the one responsible, invoking the Old Testament tradition for this concept of hardness of heart!

8 E.j. Malbon (1986:104-130) has illustrated the similarities at times between the responses of the crowd and that of the disciples to the message of Jesus: "Given the opportunity for hearing and difficulty in understanding that the disciples and the crowd share, it is not surprising that they also share a response of amazement, astonishment, and even fear in relation to Jesus. The crowd is amazed, astonished at Jesus' teaching $(1: 22$, they $[1: 27, \pi \hat{c}]$,

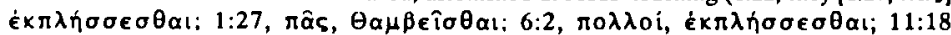

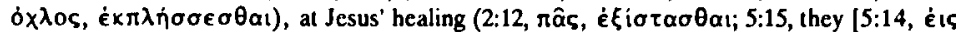

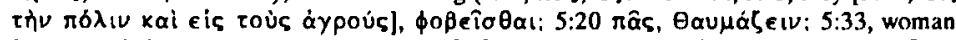

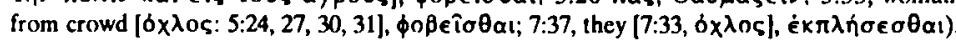
at Jesus himself $\left(9: 15\right.$, $\left.\pi \hat{\alpha} \varsigma \delta \delta \times \lambda o s, \dot{\epsilon} \times \theta \alpha \mu \beta \in \hat{\imath} \sigma \theta \alpha_{1}\right)$. The disciples are amazed astonished at Jesus' teaching [10:24, $\mu \alpha \theta \eta \tau \alpha i, \theta \alpha \mu \beta \in \hat{i} \sigma \theta \alpha$; 10:26, they [10:24, $\mu \alpha \theta \eta \tau \alpha i]$

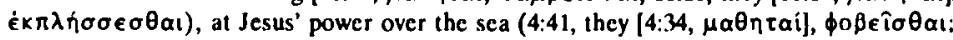

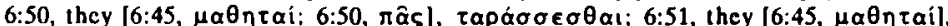

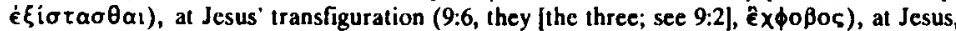
prediction of his passion and resurrection $(9: 32$, they $[9: 31, \mu \alpha \theta \eta \tau \alpha i], \phi \circ \beta \in[\sigma \theta a i)$. 
Jesus suggests to his disciples that they cross the lake (Mk 4:35). But, when the storm breaks out, the disciples turn on Jesus and rebuke him: "Teacher, do you not care that we are perishing?" (Mk 4:38).

Having stilled the storm, Jesus upbraids the disciples for their lack of faith: "Why are you afraid? Have you still no faith?" (Mk 4:40). The disciples' reaction to Jesus, both to his miraculous stilling of the storm, as well as to his stinging rebuke, is worth noting: "And they were filled with great awe and said to one another, 'Who then is this, that even the wind and the sea obey him?"' (Mk 4:41). The disciples are not, as we, the reader, might expect, followers who are impressed with what Jesus has done - instead they are filled with fear. A distance is beginning to open up between them and Jesus. From insiders, who are bonded together with the protagonist, Jesus, they now become people who look on Jesus with fear and suspicion. As the reader, we begin to ask ourselves the question: 'Will the disciples endorse the person and message of Jesus, or will they continue to distance themselves from him?'

In crossing to the other side of the lake, Jesus enters Gentile territory (Mk 5:1). The change in setting shows how Jesus' proclamation now moves to pagans as well. This episode of the healing of the Gerasene demoniac (Mk 5:1-20) involves an exorcism which occurs in Gentile territory. This parallels the beginning of the public ministry of Jesus in Galilee. The first event that the narrator recorded was an exorcism which Jesus performed in the town of Capernaum (Mk 1:21-27). Now the first event Jesus performs in Gentile territory is again an exorcism. This parallel shows that Jesus' proclamation is directed both to Jews and to Gentiles and that his task remains the same: to liberate both Jews and Gentiles from the power of evil. The territory of the Gentiles has now been liberated from the power of evil: they too can enter the kingdom proclaimed by Jesus.

On returning via the lake to Jewish territory, Jesus performs a somewhat different miracle from those hitherto performed, namely the raising of the daughter of Jairus to life. This is not just a healing; it is the bringing back to life of a dead person. Again the narrator draws a distinction between insiders and outsiders: the only people privileged to witness the miracle are the three closest disciples: Peter, James and John (Mk 5:40). In a very pointed way the narrator indicates to us, the reader, that these three (Peter, James and John) have had the privilege of witnessing the greatest of Jesus' miracles, namely his power over death. Therefore, they should have the deepest understanding of Jesus' person. This miracle should prepare them for what is to come, namely Jesus' death and his victory over death. But, in fact, they were not prepared, as events subsequently demonstrate. 
Between Mark 5:43 and 8:13 Jesus had crossed the Lake once again (Mk 5:53), he had ministered in the regions of Tyre and Sidon (Mk 7:24) as well as in the Decapolis region (Mk 7:31). This shows that the message of the kingdom is being proclaimed to Gentiles. In Mark 8:1-8 the second feeding of the crowd occurs - this time in Gentile territory. The section concludes with the return of Jesus and the disciples by boat to the Jewish side of the Sea of Galilee (Mk 8:14-21). A conflict emerges between Jesus and his disciples. The narrator shows the reader that the disciples had failed to grasp the meaning of what Jesus was doing. They had one loaf of bread among them, and yet they spoke about having no bread. Their problem was that they were unable to see what they actually had. They asked for loaves of bread, when in fact they already had some. Kelber (1979:40) expresses well this lack of perception of the disciples:

The truth is what they have but cannot see. They have one loaf which embodies the oneness of Jews and Gentiles. This oncness Jesus had manifested during the boat trips. The loaf they have is symbolic of the unity of all. This is what the voyages were all about.

Jesus went on to rebuke the disciples with those same words that he used to separate 'insiders' from 'outsiders' in his parable discourse. "Do you still not yet perceive or understand? Are your hearts hardened? Do you have eyes, and fail to see? Do you have ears, and fail to hear?" (Mk 8:17-18).

The narrator has brought us, the reader, to see the lack of understanding and lack of faith the disciples have in their master. As Jesus begins his journey towards Jerusalem, where suffering and death await him, the disciples are no longer in the position of 'insiders' who perceive who Jesus is and what he is to accomplish. As the reader, we are led to expect that something tragic is to occur in the relationship between Jesus and his followers.

\section{RESPONSE OF DISCIPLES TO JESUS' ANNOUNCEMENT OF HIS DEATH ON THE JOURNEY TO JERUSALEM (Mark 8:22-10:52)}

The narrative continues with the focus on Jesus' impending death and his attempt to prepare his followers for this event. From the way in which the account is narrated the reader is given more understanding regarding Jesus' person, and his disciples' character, as well as the importance of suffering in the mission of Jesus. This section unfolds through the movement to Jerusalem, the place of Jesus' suffering and death. 
The narrator has presented this narrative within a very careful framework. It commences with an episode in which the eyes of a blind man are opened at Bethsaida (Mk 8:22-26). Then, the whole section concludes with a further healing of a blind man, Bartimaeus (Mk 10:46-52). Framed in this manner, attention is given to opening the eyes of those who are blind. In particular one can see Jesus trying to open the eyes of his disciples along the road to Jerusalem (Kelber, 1979:44).

But, to what exactly is it that Jesus wishes to open the eyes of the disciples? The answer emerges from a statement Jesus makes on three separate occasions: the prediction of his passion and resurrection (Mk 8:31; 9:31; 10:33-34). By means of this threefold repetition, the narrator draws the reader's attention to the importance of this event.

While all three predictions are intended for the disciples, one observes how the audience becomes more and more refined. The first prediction is addressed to the wider group of disciples (8:31); the second is also addressed to the disciples, but explained only to the twelve $(9: 35)$; while the third prediction has only the twelve in mind (10:33). Attention focuses on the inner core of disciples, the twelve: Jesus wants them, in particular, to absorb the message of the purpose of his life: to die in Jerusalem.

Since almost half the Gospel focuses upon the suffering and death of Jesus, this is the most important aspect of the life of Jesus which the narrator wishes to communicate to the readers. Jesus fulfils the role of a martyr whose life work is orientated towards giving himself in death on behalf of others. At the same time Jesus' role is one that every disciple should wish to emulate in turn. The aim of this communication, this Gospel, emerges here: the disciple is called to be a follower of Jesus, to imitate his way of life in every aspect. Central to the life of Jesus is his path to suffering and death. Every follower of Jesus is called to accept suffering in his/her own life. In doing so, one is a true disciple, following the way of the Lord.

At the end of the first prediction of his suffering and death, Jesus makes an application to his hearers: "If any want to become my followers, let them deny themselves and take up their cross and follow me. For those who want to save their life will lose it and those who lose their life for my sake, and for the sake of the gospel, will save it" (Mk 8:34-35). The message that the narrator of Mark's Gospel communicates, and does so very forcefully, is the positive significance that suffering plays in life. To be a disciple means that one follows the life of Jesus: one has to be prepared to accept suffering 
and to show a concern above all for others, rather than for oneself.

But, this passage (Mk 8:34-35) needs to be read in conjunction with what preceded it (Mk 8:27-33). In reply to Peter's confession that Jesus is the Messiah, Jesus responds by telling the disciples that he has to suffer and die. In other words, although the confession of Peter is remarkable, it does show a false understanding of who Jesus is. He may be the Messiah, but he is no glorious and triumphant Messiah - he is a suffering and dying Messiah. When Peter hears this, he rejects what Jesus says, by saying that he will not allow this to happen. Jesus, in his turn, rebukes Peter for failing to accept the plan that God has for Jesus.

The reader perceives once again the failure of Peter and the disciples to grasp Jesus' teaching. The narrator goes on to highlight the inadequacy of the disciples when he narrates the dispute among the disciples themselves as regards who is the greatest (9:33-37). This occurs immediately after Jesus has spoken about his death for the second time. Rather than show concern for what Jesus has just said, the disciples demonstrate a preoccupation with their own positions and power. The third prediction of the passion is followed by a further account, this time dealing with the twelve, in which James and John request to be allowed to sit on the right and left hand of Jesus when he comes into his kingdom (Mk 10:35-45). Once again the desire for power and position occupies the concern of the disciples. The responses of the disciples to Jesus' teaching on his imminent suffering and death are without doubt tactless, selfish, and they show that they have completely misunderstood Jesus' teaching: the most culpable of all are Peter, James and John.

Ironically those on the inside fail to see, while some of those on the outside do see. Despite the special teaching that Jesus addresses to his followers, they still continue to misunderstand all he says to them. On the other hand, this section concludes with the communication of sight to the blind man, Bartimaeus, who ended up by following Jesus "on the way" (Mk 10:52). For us, the reader, we are given insight into the tragedy of those first followers of Jesus who, despite all the efforts of Jesus, still could not come to a true understanding.

\section{THE DISCIPLES AS OUTSIDERS: JERUSALEM AND JESUS' DEATH (Mark 11:1-15:47)}

Jerusalem, the religious centre of Palestine, is the setting towards which the whole narrative of Mark's Gospel has been leading. As the disciples enter Jerusalem, it does 
seem that they are not really conscious of the impending death of Jesus. They do profess a distinct loyalty to him (Rhoads \& Michie, 1982:127). When Jesus says that one of them will betray him, they ask: "Surely, not I?" (Mk 14:19). Peter expresses his usual boldness in saying: "Even though I must die with you, I will not deny you" (Mk $14: 31)$.

But, three times Peter publicly denied Jesus (Mk 14:66-72). This is the culmination of the disciples' inability to remain true to Jesus. One of the disciples had denied him, the three closest ones had failed to support him in his hour of trial, and the very leader of the group had disowned Jesus three times. This tragedy of the response of the disciples is something for which the narrator has prepared the reader right from the beginning of the narrative. This response is as one would expect it. The final reference in the narrative to the disciples ends with this denial.9

The confession of the centurion: "Truly this man was God's Son!" (Mk 15:39) counterbalances the response of the disciples. This acknowledgement could only really take place in an encounter with his death, for it is through death that Jesus' identity emerges.

\section{THE OPEN-ENDEDNESS OF THE NARRATIVE (Mark 16:1-8)}

The narrative ends (Mk 16:1-8) with a group of women at the tomb. They had observed the crucifixion from a distance $(\mathrm{Mk} \mathrm{15:40)}$ and had seen where the body of Jesus was placed when it was taken down from the cross (Mk 15:47). They had come to anoint Jesus' body, but discovered that "he has been raised; he is not here" (Mk 16:6). They are instructed by the young man at the tomb: "But go, tell his disciples and Peter, that he is going ahead of you to Galilee; there you will see him, just as he told you" ( $M k$ 16:7). But, the women were overcome by fear, and they fled, just as the disciples had fled earlier. And the narrator comments: "... they said nothing to anyone, for they were afraid" (Mk 16:8). On this note the Gospel ends.

Freyne (1982:7-23) has made a number of interesting observations on the silence of the women. He observes that one of the features of apocalyptic literature is the call to

9 At the arrest of Jesus the narrator observes: "All of them deserted him and fled" (Mk 14:50). This is then followed by the episode of the young man who ran away naked (Mk 14:51-52). All the accounts reinforce the picture of the intimate band of Jesus' followers turning from 'insiders' to 'outsiders'.

Koers 58(1) 1993:35-52 
remain silent until the appropriate time. For example, in the book of Daniel the implication given is that Daniel's experiences are to be entrusted to writing, but the book is to be kept hidden until the appropriate time: "Go your way, Daniel, for the words are to remain secret and sealed until the time of the end" (Dan. 12:90). Coupled with the command to silence goes the theme of fear and awe that greets the visions that Daniel experiences. "As for me, Daniel, my spirit was troubled within me, and the visions of my head terrified me" (Dan. 7:15. See also 7:28; 8:18.27; 10:7-9).

Freyne argues that the Gospel of Mark can be seen to make use of such apocalyptic expressions. When one encounters the experience of revelation, the appropriate response is that of fear and silence. There is a certain amount to be said for this argumentation, especially seeing that the apocalyptic imagination is something that certainly influences Mark and without doubt accounts for the silences called upon by Jesus throughout the narrative for those who encountered his miracles. However, this does not adequately account for the instruction of the young man: "Go, tell his disciples and Peter" (Mk 16:7). The instruction in effect is to break the silence; the women instead still keep the silence and do not carry out the instruction.

One could say that the women failed to understand that the time had now come when their encounter with the revelation of the risen Jesus is to be proclaimed openly. However, the lack of understanding of the event leads them to fear and silence. Instead of closure, the book now remains open to the reader to become an 'insider' and to understand the message.

There is much discussion as to whether the Gospel actually ended here at Mark 16:8. Most ancient manuscripts contain this as the ending. However some other ancient manuscripts contain a longer ending (Mk 16:9-20), or even a shorter one. This is probably due to the fact that some commentators could not understand how a Gospel could end on a note of fear, and thus found the need to provide a more positive ending. ${ }^{10}$ This they did by making a summary of the endings of Matthew and Luke and

10 It is also interesting to note what both Matthew and Luke did to this ending of Mark. Both of them were obviously unhappy with the way in which Mark had ended the story, so they changed it, as can be seen from the following comparison:

Mark 16:8 - "So they went out and fled from the tomb, for terror and amazement had seized them; and they said nothing to anyone for they were afraid."

Matthew 28:8 - "So they left the tomb quickly with fear and great joy, and ran to tell his disciples."

Luke 24:9 - "... and returning from the tomb, they told all this to the eleven and all the rest." 
adding this to the ending of Mark. However, to my mind the ending at Mark 16:8 makes perfect sense.

The response of the women to the message of the resurrection is what we, the reader, have been led to expect from the disciples of Jesus. Just as the disciples had failed to come to an awareness and acceptance of the suffering of Jesus, as well as a suffering discipleship, so too the women fail to see beyond the suffering Jesus. When the climax of the narrative was reached, which Jesus had consistently taught (namely, that he is risen), they ran away in fear.

Consistently, the disciples have failed to understand the teaching of Jesus. In this way the narrator has presented the disciples as examples to be avoided, not imitated. The only person whom the reader is exhorted to imitate is Jesus: "If any want to become my followers, let them deny themselves and take their cross and follow me" (Mk 8:34). That instruction was addressed to the disciples of Jesus, but they failed to understand its meaning and its urgency. By presenting the disciples as failing to comprehend, the narrator is indirectly addressing the reader and making an appeal to the reader to be the one to accept and adopt these words of Jesus.

This corresponds to what Ong has emphasized about oral narratives, namely that they tend to be very polemical, or as he terms it "agonistically toned" (Ong, 1982:195-207; see also Dewey, 1989:42-44). In fact instruction often entails how one should not behave (see Havelock, 1963:48). It is in this sense that the 'open ending' of Mark 16:8 functions. By calling the narrative 'open ended' one indicates that one is left unsure of what ultimately happened to the disciples and women in the narrative. The imagination of the reader is left to visualize two possibilities: the possibility that the disciples could ultimately meet the risen Jesus and so change (Mk 16:7), or that they could be so wrapped up in their fears and anxieties that they failed to appreciate that there was the possibility of a new beginning (Tannehill, 1977:404).

The openness of the narrative invites the reader's response. The message of the kingdom in Mark is not that of a proclamation, but rather of interpretation (Kelber, 1979:5). We, the readers, have seen what has happened to the disciples. By sharing in the omniscience of the narrator, we have been prepared for the final outcome. However, the openness of the narrative issues a challenge and warning to us, the readers, not to behave as did the disciples. The openness of the narrative includes the readers now as the new insiders. The narrative truly challenges the reader to grasp the meaning. Within the structure of the narrative the negativity that the disciples receive 
is to be viewed as a foil which the author is using in order to bring across the instruction of his own community.

While the narrative presents the disciples negatively to illustrate how discipleship vacillates, it is not the intention of the author to conduct a vendetta against historical disciples. Since the work of Weeden (most noteably in 1968 and 1971), it has been fashionable to argue that Mark is conducting a polemic against the historical disciples with the direct intention of discrediting them. Such an historicizing approach fails to realize that textualization in itself is a way of distancing oneself from the socialhistorical world. A one to one correlation between the world of the text and the socialhistorical world cannot immediately be made. ${ }^{11}$

In the final analysis the narrative with its open ending becomes a moral example (Dewey, 1989:43) challenging the reader to action. As insiders the disciples have been given an understanding of the meaning of the kingdom, and the whole narrative strains forward towards disclosure, towards making known what has been hidden. This is in line with the very nature of narrative which sets out to reveal, not to hide. Kelber has endeavoured to demonstrate how the narrative of Mark's Gospel aims at revealing/disclosing what is hidden: "In this sense the gospel does not at all present itself as a patron of secrecy, but rather as an ardent demythologizer of the myth of esoteric secrecy" (Kelber, 1979:11).

The ending of Mark's Gospel stands out as the disciples' betrayal of the role entrusted to them. They had been given an insight into the meaning of the kingdom. But, this was not meant to be kept secret, but to be shared with others. This they failed to do. Instead, the final scene shows a group of women continuing to remain silent.

The real aim of narrative criticism is to show the reader a new way of being in the world. As Paul Ricoeur (1981:112) says:

What is to be interpreted in the text is a proposed world which I could inhabit and in which I could project my ownmost possibilities.

The disciples had had the privilege of being the initial insiders in the narrative. However, they lose this position to the reader. The narrator shares his omniscience

11 While the focus of attention has been directed throughout this paper on narrative criticism in its relation to the Gospel of Mark, I am not making an argument for its substitution for the historical-critical method. As stated at the beginning, both methods operate with different aims, trying to answer different questions. I believe that taken together, they provide the interpreter/reader with a wider perception of the meaning of the text. 
with the reader and in this way the reader is given a wider perception of the whole unity of the narrative. The open ending of the narrative invites the reader into this role of the new insiders (Kelber, 1988:15).

Our focus of attention on the end of the narrative should not lose sight of Fowler's valuable observation:

The entire reading experience is to be valued - not just the end product of reading. Reading a text is a rich and dynamic experience; but focusing on the end product of reading lends itself to perceiving a text as a static, spatial form, like a painting or sculpture or a piece of architecture. (Fowler, 1983:49)

The reading experience is in fact a temporal experience in which all aspects of the experience have their importance, not just the final one. At times it appears that attention is given solely to the outcome of the reading, to what happened at the end. Consequently, the path that the reader followed ultimately to reach that goal is forgotten or ignored. To appreciate the vacillation of the disciples in following Jesus is just as important as the final scene of the enigma of their ultimate commitment.

\section{BIBLIOGRAPHY}

BAL. M. 1988. Narratology. Introduction to the Theory of Narrative. Tr. by C. van Boheemen, Toronto Universily of Tornnto Press.

BEST, E. 1977. The Role of the Disciples in Mark. New Testament Studies, 23:377-401.

DEWEY, J. 1989. Oral Mcthods of Structuring Narrative in Mark. Interpretation, 43:32-44.

FAY, G. 1989. Introduction to Incomprehension: The Literary Structure of Mark 4:1-34. Catholic Biblical Quarerly, 5165-81.

FOWLER, R. 1978. The Feeding Stories in the Gospel of Mark. PhD diss., University of Chicago.

FOWLER, R. 1983. Who is "the Reader" of Mark's Gospel? Society of Biblical Literature Seminar Papers: $31-53$.

FREYNE, S. 1982. The Disciples in Mark and the Maskilim in Danicl. A Comparison. Joumal for the Study of the New Testament, 16:7-23.

HAVELOCK, E.A. 1963. Preface to Plato. Cambridge : Belknap of Harvard University

KELBER. W.H. 1979. Mark's Story of Jesus. Philadelphia : Fortress.

KELBER, W.H. 1987. Narrative as Interpretation and Interpretation as Narrative: Hermeneutical Reflections on the Gospels. Semeia, 39:107-133.

KELBER, W.H. 1988. Narrative and Disclosure: Mechanisms of Concealing. Revealing, and Reveiling. Semeia, 43:1-20

MALBON, E.S. 1986. Disciples/Crowds/Whoever: Markan Characters and Readers. Novum Testamentum, 28104-130.

MATERA, F.J. 1989. The Incomprehension of the Disciples and Peter's Confession (Mark 6,14-8,30). Biblica, 70:153-172. 
MUNRO, W. 1982. Women Disciples in Mark? Catholic Biblical Quanerly, 44:225-241.

O'COLLINS, G, 1988. The Fearful Silence of Three Women (Mark 16:8c). Gregorianum, 69:489-503.

ONG, W.J. 1982. Orality and Literacy: The Technologizing of the Word. London : Methuen.

PERRIN, N. 1972. The Evangelist as Author: Reflections on Method in the Study and Interpretation of the Synoptic Gospels and Acts. Biblical Research, 17:5-18.

PETERSEN, N. 1980. Literary Criticism in Biblical Studies. (In Spencer, R.A. ed. Orientation by Disorientation. Pittsburgh : Pickwick Press. p. 25-50.)

RHOADS, D. 1982. Narrative Criticism and the Gospel of Mark. Joumal of the American Academy of Religion, 50:411-434

RHOADS, D. \& Michie, D. 1982. Mark as a Story: An Introduction to the Narrative of a Gospel Philadelphia : Fortress.

RICOEUR, P. 1981. Hermeneutics and the Human Sciences. Essays on Language, Action and Interpretation. Ed. by J.B. Thompson. Cambridge : Cambridge University Press.

TANNEHILL, R.C. 1977. The Disciples in Mark: The Function of a Narrative Role. Joumal of Religion, 57:386-405.

USPENSKY, B. 1973. Poetics of Composition. (Translated by Zavarin, V. and Wittig, S.) Berkeley : University of California Press.

WEEDEN, T.J. 1968. The Heresy that Neccssitated Mark's Gospel. Zeitschrift für Neutestamentliche Wissenschaft, 59:145-158.

WEEDEN, T.J. 1971. Mark: Traditions in Conflict. Philadelphia : Fortress. 